\title{
Comparative karyotypic analysis in the Alstroemeria hookeri Lodd. (Alstroemeriaceae) complex sensu Bayer (1987)
}

\author{
Carlos Baeza, Eduardo Ruiz and María Negritto \\ Departamento de Botánica, Facultad de Ciencias Naturales y Oceanográficas, Universidad de Concepción, \\ Concepción, Chile.
}

\begin{abstract}
Alstroemeria L. (Alstroemeriaceae) is an American genus of monocots with two principal distribution centers in Chile and Brazil. In Chile, it is represented by about 32 species, most of them in central Chile, an area known for its high level of endemism. The "complex" Alstroemeria hookeri is endemic to Chile, where it is distributed from the Coquimbo to the Bío-Bío Region. We analyzed the karyotypes of 36 populations of this complex along its natural distribution. Ten metaphases per population were used for chromosome measurements. All analyzed subspecies presented a well defined asymmetric karyotype. The populations of $A$. hookeri subsp. hookeri collected in the coastal range of the Bío-Bío Region and the populations from the Central Valley of this Region (Pangal del Laja) presented striking morphological differences in the karyotype, mainly on chromosome 3 . The population of $A$. hookeri subsp. recumbens from Pichicuy showed a polymorphism on chromosome 7, which differed from the other analyzed populations of this subspecies. Phenetic analysis suggested that $A$. hookeri subsp. cummingiana, which showed a more symmetrical karyotype and did not grow in sandy soil, should be alocated to $A$. cummingiana rather than considered as part of the hookeri complex.
\end{abstract}

Key words: Alstroemeria hookeri, complex, karyotype, polymorphisms, Chile.

Received: July 30, 2009; Accepted: October 29, 2009.

\section{Introduction}

Alstroemeria L. is a South American genus of Alstroemeriaceae that includes around 50 species found from Brazil to the Patagonian Region of Argentina and Chile in highly diverse habitats ranging from sea level to $4.000 \mathrm{~m}$ of altitude (Bayer, 1987; Ravenna, 1988; Sanso, 2002; Aagesen and Sanso, 2003). Central Chile is recognized as a center of diversity for this genus (Bayer, 1987), with satellite distributions occurring in central and eastern Brazil. Approximately 32 species grow in Chile; between $20^{\circ} \mathrm{S}$ and $53^{\circ} \mathrm{S}$, with most of the taxa being found between $28^{\circ}$ and $37^{\circ} \mathrm{S}$ (Bayer, 1987; Muñoz and Moreira, 2003). The great diversity of environments of this region has resulted in high levels of endemism in central Chile (Arroyo, 1995). Alstroemeria is one of the most diverse genera of Chiles vascular flora, providing an enormous and comprehensive floristic and morphological variability, especially in the coloration and ornamentation of the flowers, as evidenced by Muñoz and Moreira (2003).

The Chilean species of Alstroemeria have acquired economic relevance as ornamental plants, due to the beauty of their flowers (Buitendijk et al., 1997). Many of the spe-

Send correspondence to Carlos Baeza. Departamento de Botánica, Facultad de Ciencias Naturales y Oceanográficas, Casilla 160-C, Universidad de Concepción, Concepción, Chile. E-mail: cbaeza@udec.cl. cies have acquired considerable commercial value and are cultivated in different countries, such as Holland, Great Britain, Japan and the USA (Baeza et al., 2007a). The main factors contributing to this success are the harvest durability of the flowers and the attractiveness of the perigonium.

Sanso (2002) published interesting data on the karyological analysis of seven Andean Alstroemeria taxa. In this study, supernumerary chromosomes (B chromosomes) were reported in most of the analyzed metaphases of Alstroemeria hookeri subsp. recumbens (Herbert) Bayer, but the other subspecies of the complex were not considered. B chromosomes had already been reported for Alstroemeria angustifolia subsp. angustifolia (Buitendijk and Ramanna, 1996) and their occurrence may confer a selective advantage in relation to plants without them (Holmes and Bougourd, 1989, 1991)

The A. hookeri complex is endemic to Chile and occurs in the Central Chilean Zone, where the largest number of Chilean species are found and high levels of endemism exist (Villagrán et al., 1994; Teneb et al., 2004).

Four subspecies of Alstroemeria hookeri are recognized (Bayer, 1987): A. hookeri Lodd subsp. hookeri (from the Bío Bío and Maule Regions), A. hookeri. subsp. recumbens (Herbert) Bayer (endemic to the Valparaíso Region), A. hookeri subsp. maculata Bayer (endemic to the Coquimbo Region) and $A$. hookeri subsp. cummingiana 
(Herbert) Bayer from the Metropolitana, Valparaíso and Coquimbo Regions. Muñoz and Moreira (2003) recognized only three subspecies in the $A$. hookeri complex: A. hookeri subsp. hookeri, A. hookeri subsp. maculata and A. hookeri subsp. recumbens. A. cummingiana was maintained as a different species.

Baeza et al. (2007b) and Cajas et al. (2009) found differences between the karyotypes of populations of $A$. hookeri subsp. hookeri from the Central Valley and from the coastal range in the Bío-Bío Region of Chile. The karyotypes of the coastal and eastern populations were remarkably different, mainly regarding their chromosome 3 . In the coastal range populations, this chromosome was telocentric, whereas in the eastern populations, it was metacentric. In addition, there were differences between chromosomes 4 and 8 of both karyotypes. Chromosome 4 was telocentric and chromosome 8 was submetacentric in the coastal range populations, whereas both chromosomes were subtelocentric in the eastern populations.

Given these previous data in the typical subspecies and the potential ornamental value of the A. hookeri complex, the objective of this work was to expand the comparative cytological analysis of all the subspecies of this complex (sensu Bayer, 1987).

\section{Material and Methods}

\section{Plant material}

Samples of 15 individuals from 36 populations of each subspecies were collected during November and De- cember of 2007 and 2008 (Figure 1). The sources of the material studied and deposited in CONC (Herbarium code of the University of Concepción, Chile) are summarized in Supplementary Material.

\section{Methods}

Root tips with one to two $\mathrm{cm}$ in length, obtained from plants cultivated in the greenhouse, were pre-treated with a solution of 8-hydroxiquinolein $(2 \mathrm{mM})$ for $24 \mathrm{~h}$ at $4{ }^{\circ} \mathrm{C}$. They were kept in ethanol/acetic acid (3:1) for $24 \mathrm{~h}$ and stored in $70 \%$ ethanol at $-20^{\circ} \mathrm{C}$. After fixing, an acid hydrolysis was carried out with $0.5 \mathrm{~N} \mathrm{HCl}$ for $22 \mathrm{~min}$ at $45^{\circ} \mathrm{C}$. The root tips were then washed three times with distilled water and were finally stained with $1 \%$ acetic orcein. Chromosome counting, analysis, and interpretation (ten metaphases per population) were carried under a Zeiss Axioskop microscope equipped with a digital video camera. The chromosomes were measured with the MicroMeasure 3.3 software (Reeves, 2001) and were classified according to their relative arm lengths (Levan et al., 1964). The TCL (total chromosomes length plus the standard deviation in $\mu \mathrm{m}$ ) was obtained for each population; the AsK \% (asymmetry index defined by Arano and Saito, 1980), TF\% (asymmetry index defined by Huziwar, 1962), and Syi (asymmetry index defined by Venora et al., 2002) were calculated.

Total chromosome length (TCL) was calculated as the percentage of the total genomic length corresponding to a haploid set. Photographs were processed with the Paint Shop Pro X2 software. The software NTSyS-pc (Numerical

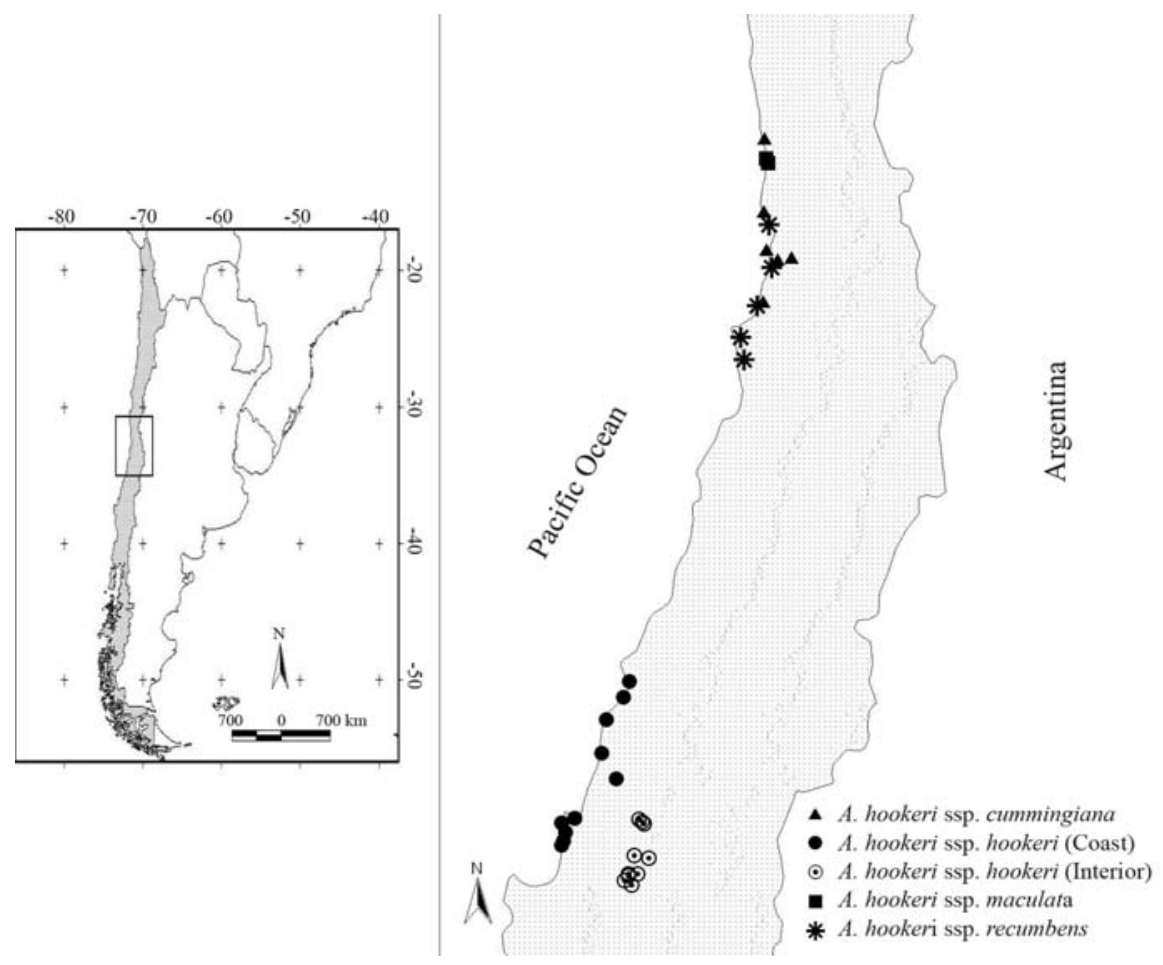

Figure 1 - Geographic distribution of the 36 analyzed populations of the Alstroemeria hookeri complex. 
Taxonomic System of Multivariate Statistical Programs; Rohlf (2005) was used to perform a phenetic cluster analysis by UPGMA.

\section{Results and Discussion}

All the analyzed samples of 36 populations had $2 \mathrm{n}=$ $2 \mathrm{x}=16$ chromosomes. Each subspecies in the complex had a different karyotype, which reflected in different asymmetry indexes and different total chromosome length (TCL) values (see Figure 2 and Table 1). Intra-subspecific varia-
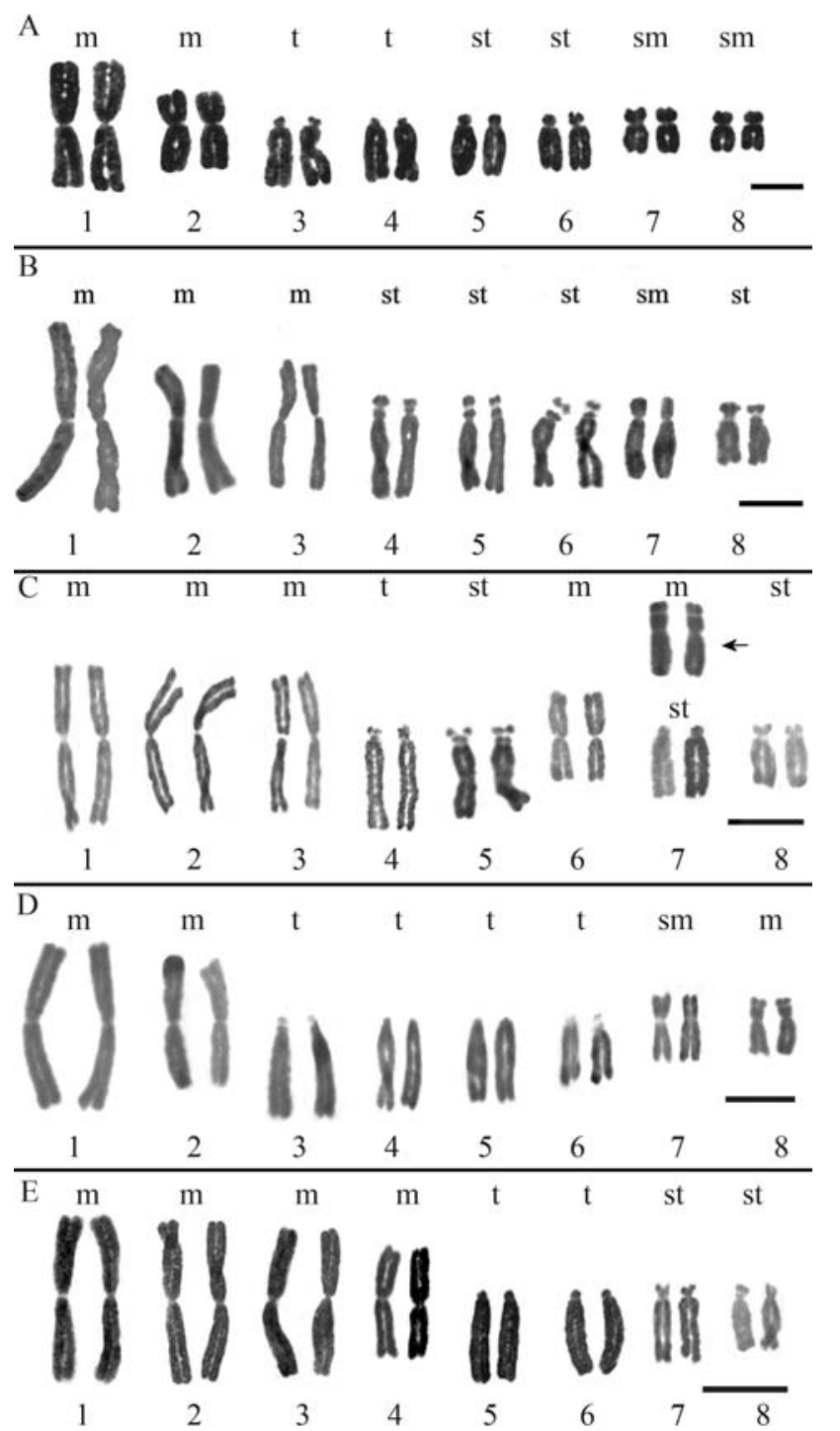

Figure 2 - Karyotypes of the Alstroemeria hookeri complex populations: (a) A. hookeri subsp. hookeri from the coastal area of the Bío-Bío and Maule Regions of Chile (populations 4181, 4182, 4202, 4211, 4220, 4221, 4222, 4224, 4226, 4227, 4235, 4286 and 4287); (b) A. hookeri subsp. hookeri from the Central Valley of the Bío-Bío Region of Chile (populations 4175, 4187, 4189, 4212, 4214, 4215, 4216, 4217, 4218 and 4219); (c) A. hookeri subsp. recumbens (populations 4271, 4273, 4275, 4283 and 4284); (d) A. hookeri subsp. maculata (populations 4277 and 4278) and (e) A. hookeri subsp. cummingiana (populations 4272, 4274, 4276, 4279, 4281 and 4282). Bar $=10 \mu \mathrm{m}$. tion was detected in Alstroemeria hookeri subsp. recumbens and $A$. hookeri subsp. hookeri. The former had four metacentric, two subtelocentric, one satellited subtelocentric and one telocentric chromosome pairs $(4 \mathrm{~m}+$ $2 \mathrm{st}+1 \mathrm{st}$-sat $+1 \mathrm{t})$, but samples from the population of Pichicuy (4275) showed a different morphology in chromosome 7 (Figure 2c). More consistent differences were found in A. hookeri subsp. hookeri. All the populations of this taxon from the coastal range of the Bío-Bío Region had a karyotype with $2 \mathrm{~m}+2 \mathrm{sm}+2 \mathrm{st}+2 \mathrm{t}$ chromosome pairs (Figure 2a) and all the populations from the Central Valley had $3 \mathrm{~m}+1 \mathrm{sm}+4 \mathrm{st}$-sat chromosome pairs (and a more symmetrical karyotype; Figure $2 \mathrm{~b}$, Table 1). Although the most conspicuous difference between coastal and Central Valley populations was on chromosome 3 , small but consistent differences in chromosomes 4 and 8 were also found. No intra-subspecific differences were detected in the other two subspecies. A. hookeri subsp. maculata had an asymmetric karyotype with a $2 \mathrm{~m}+1 \mathrm{~m}$-sat $+1 \mathrm{sm}+$ 1 st-sat $+2 \mathrm{t}+1 \mathrm{t}$-sat chromosome set (see Table 1 and Figure 2d). A. hookeri subsp. cummingiana had the most symmetric karyotype with $4 \mathrm{~m}+1 \mathrm{st}+1 \mathrm{st}-\mathrm{sat}+2 \mathrm{t}$ chromosome pairs (Figure 2e) and a higher TCL value (Table 1). The UPGMA phenogram (Figure 3 ) shows the phenetic relationships among populations based on karyotypic data. The closest relationships among populations were those between $A$. hookeri subsp. hookeri from the Central Valley of the Bío-Bío Region and $A$. hookeri subsp. recumbens, and between $A$. hookeri subsp. hookeri from the coastal range and $A$. hookeri subsp. maculata. The subspecies with the most divergent karyotype was $A$. hookeri subsp. cummingiana, as shown by its largest phenetic distance from the complex.

The Alstroemeria hookeri complex is a group of morphologically very similar subspecies, which typically grow in sandy soils, mostly near the coastal zone. According to Bayer (1987), the Alstroemeria hookeri complex consists of $A$. hookeri subsp. hookeri, A. hookeri subsp. recumbens, A. hookeri subsp. maculata and A. hookeri subsp. cummingiana. Among these taxa, A. hookeri subsp. cummingiana is the only one which does not grow in sandy soils, but rather in a brownish-grey non-calcium soil, with a lightly acidic, pink to light brownish-red A horizon , and a light brownish-red or dirty red B horizon (Soil Survey Staff, 1999). During the development of this research, three populations from the Region of Valparaíso (Region $\mathrm{V}$ of Chile) were initially mistaken for $A$. hookeri subsp. recumbens, but later recognized as a new species of Alstroemeria from Chile, Alstroemeria novoana (Negritto M, Baeza C, Ruiz E and Novoa P, unpublished data). The new species also grows in soils similar to those where $A$. hookeri subsp. cummingiana is found and never in sandy soils. Many samples (ten populations) were collected in the sector Pangal del Laja, located in the central depression of the Bío-Bío Region (Supplementary Material). These pop- 
Table 1 - Karyotype features of the subspecies of Alstroemeria hookeri.

\begin{tabular}{lccccc}
\hline $\begin{array}{l}\text { Karyotype } \\
\text { characteristics }\end{array}$ & $\begin{array}{c}\text { A. hookeri subsp. } \\
\text { hookeri (Coast) }\end{array}$ & $\begin{array}{c}\text { A. hookeri subsp. hookeri } \\
\text { (Central Valley) }\end{array}$ & $\begin{array}{c}\text { A. hookeri subsp. } \\
\text { recumbens }\end{array}$ & $\begin{array}{c}\text { A. hookeri subsp. } \\
\text { maculata }\end{array}$ & $\begin{array}{c}\text { A. hookeri subsp. } \\
\text { cummingiana }\end{array}$ \\
\hline $\begin{array}{l}\text { Karyotype } \\
\text { formula }\end{array}$ & $2 \mathrm{~m}+2 \mathrm{sm}+2 \mathrm{st}+2 \mathrm{t}$ & $3 \mathrm{~m}+1 \mathrm{sm}+4 \mathrm{st}$-sat & $4 \mathrm{~m}+2 \mathrm{st}+1 \mathrm{st}$-sat $+1 \mathrm{t}$ & $\begin{array}{c}2 \mathrm{~m}+1 \mathrm{~m} \text {-sat }+1 \mathrm{sm}+ \\
1 \mathrm{st}-\mathrm{sat}+2 \mathrm{t}+1 \mathrm{t}-\mathrm{sat}\end{array}$ & $4 \mathrm{~m}+1 \mathrm{st}+1 \mathrm{st}-\mathrm{sat}+2 \mathrm{t}$ \\
$\mathrm{TCL}(\mu \mathrm{m})$ & $180.82 \pm 8.2$ & $251.16 \pm 7.6$ & $179.36 \pm 7.2$ & $157.06 \pm 5.8$ & $184.12 \pm 5.5$ \\
AsK $\%$ & 71.50 & 67.02 & 65.90 & 71.30 & 64.20 \\
TF\% & 28.50 & 32.98 & 34.10 & 28.70 & 35.80 \\
Syi $\%$ & 39.84 & 49.21 & 51.65 & 40.28 & 55.74 \\
\hline
\end{tabular}

$\mathrm{TCL}(\mu \mathrm{m})=$ Total chromosome length plus standard deviation. AsK $\%=$ Asymmetry index of Arano and Saito $(1980), \mathrm{TF} \%=$ Asymmetry index of Huziwara (1962), Syi = Asymmetry index of Venora et al. (2002).

ulations have been considered A. hookeri subsp. hookeri for a long time, but, when thoroughly tested by combined cytological (Cajas et al., 2009), morphological and isoenzymatic analyses (Ruiz E, Balboa K, Negritto M, Briceño $\mathrm{V}$ and Baeza M, unpublished data), these populations revealed enough features to allow their classification as a new subspecies within the $A$. hookeri complex. This new subspecies also grows in sandy soils and corresponds to populations $4175,4187,4189,4212,4214,4215,4216$, 4217, 4218 and 4219 (Table 1). The ability to grow in such soils is therefore an exclusive feature of plants from the $A$. hookeri complex.

Previous cytogenetic studies in this complex have reported the presence of B chromosomes in A. hookeri subsp. recumbens (Sanso, 2002). Such chromosomes have been reported in other complexes such as $A$. angustifolia subsp. angustifolia (Buitendijk and Ramanna, 1996), a common species in the Region of Valparaíso, very similar to $A$. hookeri subsp. recumbens. After analyzing about 1000 metaphases in all subspecies of the complex, we found no evidence of $\mathrm{B}$ chromosomes in Alstroemeria hookeri. Sanso (2002) indicated that the material was collected in Longotoma, Region of Valparaíso, at $225 \mathrm{~m}$, an unlikely habitat for $A$. hookeri subsp. recumbens because this plant grows in sandy soil and very close to the coast. Therefore, the presence of $\mathrm{B}$ chromosomes must be considered with caution in the A. hookeri complex. Many of the publications on the cytology of Alstroemeria from Chile have used plants grown in European greenhouses, sometimes with identification errors leading to mistakes like the one mentioned above. More work should be carried out on wild populations of Alstroemeria because cultivated material may present remarkable changes in leaf morphology and tepal color, which may lead to species misidentification.

The phenogram in Figure 3 shows three groups of populations. The first group is formed by $A$. hookeri subsp. hookeri from the coast of the Bío-Bío Region and by $A$. hookeri subsp. maculata from the Coquimbo Region. Both subspecies showed very similar karyotypes; which had identical pairs 1 through 4, pairs 5, 6 and 8 differing in their morphology (Figure 2a and 2d) and.a submetacentric chro- mosome 7 . The total chromosome length $(\mu \mathrm{m})$ was a distinguishing character because its value was much higher in $A$. hookeri subsp. hookeri than in A. hookeri subsp. maculata (Table 1). Both subpecies grow in coastal areas very close to the sea. The second group is composed by $A$. hookeri subsp. recumbens from the Valparaiso Region and by $A$. hookeri subsp. hookeri from the Central Valley of the Bío-Bío Region (the new subspecies within the complex). These two taxa were the most phenetically similar within the complex. Their first three chromosome pairs were identical, all metacentric and the largest in the karyotype, while pairs 4, 6 and 7 showed differences in morphology. A remarkable difference was observed on chromosome 6: it was a metacentric in $A$. hookeri subsp. recumbens from the Central Valley of the Bío-Bío Region, a unique feature in the complex (Figure 2c), whereas it was a subtelocentric with microsatellites on the short arms in $A$. hookeri subsp. hookeri (Figure 2b). Chromosomes 5 and 8 had the same morphology (st) in both taxa. Quantitatively, the TCL was much higher in A. hookeri subsp. hookeri. Population 4275 of $A$. hookeri subsp. recumbens, collected in Pichicuy, Petorca Province (northernmost distribution area of the subspecies), presented a marked polymorphism on chromosome 7, which was a metacentric with microsatellites on the short arms (Figure 2c). This chromosome was very stable in this population and did not appear in any other populations of this taxon throughout its distribution range,

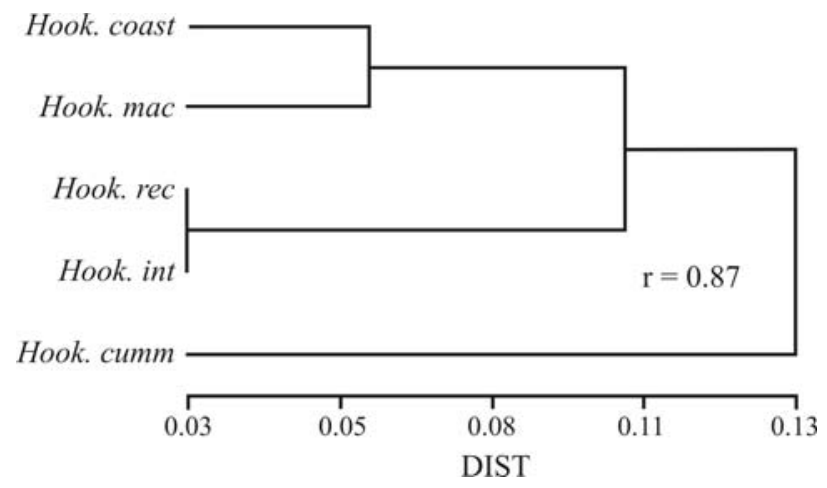

Figure 3 - Phenogram obtained with NTSys-PC, with UPGMA and DIST coefficient. 
which showed a subtelocentric 7. Polymorphisms among homologous chromosomes has been detected in other species, such as: Placea amoena (Baeza and Schrader, 2004), Brachycome (Houben et al., 2000), Alstroemeria (Buitendijk et al., 1998) and Scilla (Greilhuber and Speta, 1976), among others. However, the presence of different homologous chromosomes in different populations of the same taxon is not frequent and has only been detected in the populations of $A$. hookeri subsp. hookeri from the coast and from the Central Valley of the Bío-Bío Region (Cajas et al., 2009). Evolutionary divergence is likely to be occurring in this population of Pichicuy, which already presents chromosome variation, but no phenotypic differences yet, These results support comparative population studies of naturally growing plants throughout the distribution range of a taxa, such as A. hookeri subsp. hookeri.

Alstroemeria hookeri subsp. cummingiana appeared as the most distantly related taxon in relation to the other members of the $A$. hookeri complex. It is the only taxon with metacentric chromosomes 1-4 (Figure 2e) and it had the smallest ASK\% value (64.2), meaning that it has the most symmetrical karyotype in the group. This cytogenetic feature, combined with the habitat and floral morphology of $A$. hookeri subsp. cummingiana, allowed us to conclude that this taxon should not be part of the A. hookeri complex, but rather classified as Alstroemeria cummingiana Herbert, as previously noted by Muñoz and Moreira (2003).

\section{Acknowledgments}

This work was supported by Fondecyt grant $\mathrm{N}^{\circ}$ 1070520. We thank Dr. Karin Tremetsberger (University of Seville, Spain) and Tod Stuessy (University of Vienna, Austria) for improving the English and Patricio Novoa (Jardín Botánico Nacional, Viña del Mar) for technical assistance in field.

\section{References}

Aagesen L and Sanso M (2003) The phylogeny of the Alstroemeriaceae, based on morphology, rps16 Intron, and rbcL sequence data. Syst Bot 28:47-69.

Arano H and Saito H (1980) Cytological studies in family Umbelliferae 5. Karyotypes of seven species in subtribe Seselinae. La Kromosomo 2:471-480.

Arroyo M (1995) Plantas, hongos y líquenes. In: Simonetti J, Arroyo M, Spotorno A and Lozada E (eds) Diversidad Biológica de Chile. CONICYT, Santiago, pp 5-7.

Baeza C and Schrader O (2004) Karyotype analysis of Placea amoena Phil. (Amaryllidaceae) by double fluorescence in situ hybridization. Caryologia 57:209-214.

Baeza C, Schrader O, Ruiz E and Negritto M (2007a) Análisis comparativo del cariotipo en poblaciones de Alstroemeria aurea R. Graham (Alstroemeriaceae) de Chile. Gayana Bot 64:33-39.
Baeza C, Schrader O and Budahn H (2007b) Characterization of geographically isolated accessions in five Alstroemeria L. species (Chile) using FISH of tandemly repeated DNA sequences and RAPD analysis. Plant Syst Evol 269:1-14.

Bayer E (1987) Die Gattung Alstroemeria in Chile. Mitt Bot Staatssamml München 24:1-362.

Buitendijk J and Ramanna M (1996) Giemsa C-banded karyotypes of eight species of Alstroemeria L. and some of their hybrids. Ann Bot 78:449-457.

Buitendijk J, Boon E and Ramanna M (1997) Nuclear DNA content in twelve species of Alstroemeria L. and some of their hybrids. Ann Bot 79:343-353.

Buitendijk J, Peters A, Jan-Quené R and Ramanna M (1998) Genome size variation and C-band polymorphism in Alstroemeria aurea, A. ligtu and A. magnifica (Alstroemeriaceae). Plant Syst Evol 212:87-106.

Cajas D, Baeza C, Ruiz E and Negritto M (2009) Cytogenetics analysis in populations of Alstroemeria hookeri lodd. subsp. hookeri (Alstroemeriaceae) from Bio-Bío Region, Chile. Gayana Bot 66:117-126.

Greilhuber J and Speta F (1976) C-banded karyotypes in the Scilla hohenackeri group S. persica, and Puschkinia (Liliaceae). Plant Syst Evol 126:149-188.

Holmes D and Bougourd S (1989) B-chromosomes selection in Allium schoenoprasum I. Natural populations. Heredity 63:83-87.

Holmes D and Bougourd S (1991) B-chromosomes selection in Allium schoenoprasum II. Natural populations. Heredity 67:117-122.

Houben A, Wanner G, Hanson L, Verlin D, Leach C and Timmis J (2000) Cloning and characterization of polymorphic heterochromatic segments of Brachycome dichromosomatica. Chromosoma 109:206-213.

Huziwara Y (1962) Karyotype analysis in some genera of Compositae. VIII. Further studies on the chromosomes of Aster. Am J Bot 49:116-119.

Levan A, Fredga K and Sandberg A (1964) Nomenclature for centromeric position on chromosomes. Hereditas 52:201220.

Muñoz M and Moreira A (2003) Alstroemerias de Chile. Diversidad, Distribución y Conservación. Taller La Era, Santiago, $140 \mathrm{pp}$.

Ravenna P (1988) New or noteworthy species of Alstroemeria. Phytologia 64:281-288.

Reeves A (2001) MicroMeasure: A new computer program for the collection and analysis of cytogenetic data. Genome 44:239-443.

Rohlf F (2005) NTSYSpc, v. 2.20f. Exeter Software, NY.

Sanso A (2002) Chromosome studies in Andean taxa of Alstroemeria (Alstroemeriaceae). Bot J Linn Soc 138:451459.

Soil Survey Staff (1999) Soil Taxonomy: A Basic System of Soil Classification for Making and Interpreting Soil Surveys. 2nd edition. United States Department of Agriculture, Natural Resources Conservation Service, Washington DC, 870 pp. 
Teneb E, Cavieres L, Parra M and Marticorena A (2004) Patrones geográficos de distribución de árboles y arbustos en la zona de transición climático-mediterránea templada de Chile. Rev Chil Hist Nat 77:51-71.

Venora G, Blangiforti S, Ruffini Castiglioni M, Pignone D, Losavio F and Cremonini R (2002) Chromatin organisation and computer arded karyotyping of Triticum durum Desf. cv Timilia. Caryologia 55:91-98.

Villagrán C, Le Quesne C, Aravena J, Jiménez H and Hinojosa F (1994) El rol de los cambios de clima en el Cuaternario en la distribución actual de la vegetación de Chile central-sur. Bamb Geograp Schift 12:219-235.

\section{Supplementary Material}

The following online material is available for this article:

- List of sampling sites

This material is made available as part of the online article from http://www.scielo.br.gmb.

Associate Editor: Marcelo Guerra

License information: This is an open-access article distributed under the terms of the Creative Commons Attribution License, which permits unrestricted use, distribution, and reproduction in any medium, provided the original work is properly cited. 


\section{Annex 1}

Populations of Alstroemeria hookeri subsp. hookeri from de coastal range of the Regions of Bío Bío and Maule

VII Región. Provincia de Cauquenes. Tregualemu. 20 m, (3600’ S-7246’ W). C. Baeza 4285. Curanipe. 23 m,

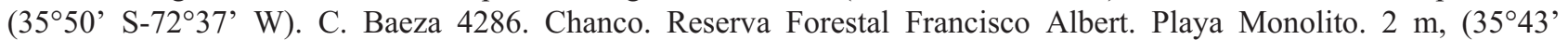
S-72³4’ W). C. Baeza 4287. VIII Región. Provincia de Concepción. Lenga, 5 m, (3646’ S-7309’ W). C. Baeza 4181. Camino de San Pedro a Coronel, sector Stadio Italiano, 30 m, (36 $54^{\prime}$ S- $73^{\circ} 08^{\prime}$ W). C. Baeza 4182 . Camino de San Pedro a Coronel, sector cruce hacia el peaje, 30 m, (36 $57^{\prime}$ S-73 $09^{\prime}$ W). C. Baeza 4202. Camino de San Pedro a Coronel, sector Bomba de Bencina YPF, 30 m, (36 56’ S-7309’ W). C. Baeza 4211. Costanera, entre Las Areneras y la entrada a Petrox (Hualpén). Bosquete de Boldo, Litre y Pelú. 10 m, (3647’ S-7306’ W). C. Baeza 4220. Hualpén. Parque. Recinto Universitario, $6 \mathrm{~m},\left(36^{\circ} 47^{\prime} \mathrm{S}-73^{\circ} 10^{\prime} \mathrm{W}\right) .18-1-2005$. Baeza 4235. Pedro de La Paz, frente a la entrada a Boca Sur. $5 \mathrm{~m}$,

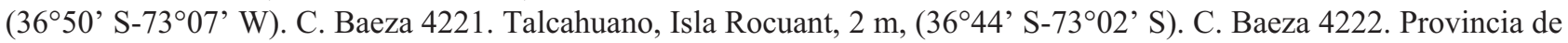
Nuble. Colmuyao, playa $2 \mathrm{~m},\left(36^{\circ} 44^{\prime} \mathrm{S}-73^{\circ} 02^{\prime} \mathrm{W}\right)$. C. Baeza 4224. Cobquecura, frente a la Lobería $2 \mathrm{~m}$, (36¹5' S-7248' W). C. Baeza 4226. Trehuaco, salida sur, 6 m, (36²6’ S-7240’ W). C. Baeza 4227.

\section{Populations of Alstroemeria hookeri subsp. hookeri from the Central Valley in the Region of Bío Bío}

VIII Región. Provincia de Biobío. Comuna de Quillón, Puente El Roble, 64 m, (36²5’ S-72²5’ W). C. Baeza 4175. Yumbel. Camino Estación Yumbel hacia Puente Perales, 102 m, (3709’ S-72³2’ W). C. Baeza 4187. Camino Estación Yumbel hacia Puente Perales, 120 m, (37¹1' S-72 34' W). C. Baeza 4189. Camino de Yumbel hacia la carretera 5 Sur,

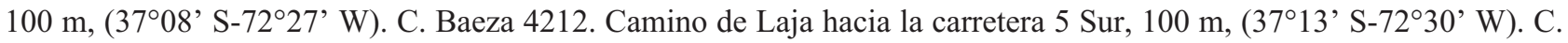
Baeza 4214. Yumbel, salida sur, $100 \mathrm{~m},\left(3^{\circ} 08^{\prime} \mathrm{S}-72^{\circ} 32^{\prime} \mathrm{W}\right)$. C. Baeza 4215. Camino entre Yumbel y Cabrero, $2 \mathrm{~km}$ al Este de Puente Ibáñez, 100 m, (3700’ S-72²9’ W). C. Baeza 4216. Camino de Cabrero a Bulnes, 3,5 km desde Cabrero, orilla ruta 5 sur $100 \mathrm{~m},\left(37^{\circ} 01^{\prime} \mathrm{S}-72^{\circ} 21^{\prime} \mathrm{W}\right)$. C. Baeza 4217. Camino hacia Quillón, sector Los Alemanes, $100 \mathrm{~m}$, (3646' S-72²4' W). C. Baeza 4218. Entrada a Quillón, casi al frente de la Laguna Avendaño, 70 m, (3644' S-72²7’ W). C. Baeza 4219 .

\section{Populations of Alstroemeria hookeri subsp. recumbens}

V Región. Provincia de Valparaíso. Dunas de Concón. Santuario. 103 m, (3256’/71³2’). C. Baeza 4271. Playa

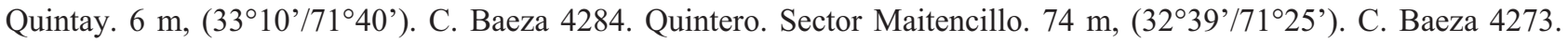
Provincia de Petorca. Pichicuy. $10 \mathrm{~m},\left(32^{\circ} 20^{\prime} / 71^{\circ} 27^{\prime}\right)$. C. Baeza 4275. Provincia de San Antonio. Algarrobo. Playa Mirasol. 2 m. (3320'/71 $\left.38^{\prime}\right)$. C. Baeza 4283.

\section{Populations of Alstroemeria hookeri subsp. cummingiana}

IV Región. Provincia de Choapa. Km 249,5 al norte de Los Vilos. 140 m, (3142’/71³1'). C. Baeza 4279. V Región.

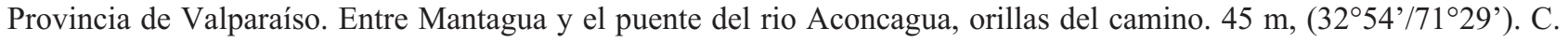
Baeza 4272. Provincia de Petorca. Zapallar, frente al cementerio. 38 m, (32 $\left.31^{\prime} / 71^{\circ} 28^{\prime}\right)$. C. Baeza 4274. Los Molles, calle La Estrella $\mathrm{N}^{\mathrm{o}}$ 743. $40 \mathrm{~m},\left(32^{\circ} 14^{\prime} / 71^{\circ} 30^{\prime}\right)$. C. Baeza 4276. Camino Maitencillo, Catapilco, km 10,86. $56 \mathrm{~m}$, $\left(32^{\circ} 35^{\prime} / 71^{\circ} 22^{\prime}\right)$. C. Baeza 4281. Inicio Cuesta El Melón, km 137, bajada norte. 169 m, $\left(32^{\circ} 34^{\prime} / 71^{\circ} 15^{\prime}\right)$. C. Baeza 4282.

\section{Populations of Alstroemeria hookeri subsp. maculata}

IV Región. Provincia de Choapa. Los Vilos. Playa Matagorda, al final, bajo el ducto de cobre de Minera Pelambre. 2 m, (31 $\left.53^{\prime} / 71^{\circ} 29^{\prime}\right)$. C. Baeza 4277. Extremo norte playa Agua Amarilla, Mal Paso, en terraza oceánica. 50 m, (31 $\left.51^{\prime} / 71^{\circ} 30^{\prime}\right)$. C.Baeza 4278. 